UDC 343.98

DOI $10.31733 / 2078-3566-2019-5-207-212$

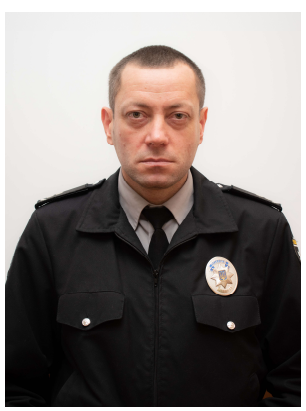

Victor PLETENETS ${ }^{\odot}$

Ph.D, Ass. Prof.

(Dnipropetrovsk State University

of Internal Affairs)

\title{
THE POSSIBILITIES OF INFORMATION SUPPORT IN OVERCOMING OF COMBATING CRIMINAL JUDICES
}

Віктор Плетенець. МОЖЛИВОСТІ ІНФОРМАЦЙНОГО ЗАБЕЗПЕЧЕННЯ В ПОДОЛАННІ ПРОТИДІї КРИМІНАЛЬНОМУ СУДОЧИНСТВУ. У статті наголошується, що ефективність розслідування кримінальних правопорушень в умовах протидії зумовлена рівнем інформаційного забезпечення цього процесу. 3 одного боку, на своєчасно отриманих відомостях грунтується пізнавальна діяльність слідчого, з іншого - прийняття ним оптимальних рішень. На підставі аналізу статистичних даних Генеральної прокуратури України зазначається, що у 60 \% кримінальних проваджень правоохоронцями не було зібрано достатньої кількості інформації, що у свою чергу, не дозволило притягнути винуватців за вчинені суспільно-небезпечні діяння.

Наголошується, що оперативно-розшукова діяльність і забезпечує процес розслідування відомостями, котрі в інший спосіб отримати складно, а іноді - неможливо. Особливого значення це набуває за умов недостатньої кількості інформації, що притаманний початковому етапу розслідування. Це варто розглядати необхідною передумовою здійснення тактичних та оперативних заходів, успішного розслідування 3 мінімізацією можливого тиску 3 боку зацікавлених осіб на учасників кримінального провадження.

Звертається увага, що системний підхід правоохоронців до інформації може зменшити витрати часу, сил та засобів на отримання позитивного результату. Невизначеність з організацією розслідування взагалі та методами подолання існуючого тиску з боку зацікавлених осіб зокрема, здебільшого, є результатом дефіциту інформації у правоохоронців. Це впливає на можливість прийняття організаційних i тактичних рішень як у визначенні напрямків розслідування, так $\mathrm{i}$ заходів з подолання протидії.

Системність, наголошується в роботі, має бути не тільки в зборі інформації, а й ії використання в кримінальному провадженні. Так, майстерно застосовані тактичні прийоми $\epsilon$ запорукою результативної слідчої (розшукової) дії, яка, у свою чергу, виступає підгрунтям для формування доказів у кримінальному провадженні. Діяльність від застосування окремо взятого тактичного прийому до розслідування взагалі має грунтуватися на наявних у правоохоронців відомостей, визначенні тих, які необхідно отримати та прогнозу реалізації цієї цілі, у тому числі 3 урахуванням наявного тиску з боку зацікавлених осіб.

У статті наводиться перелік факторів, котрі можуть впливати на результативність застосування інформаційного забезпечення та заходів, спрямованих на покращення використання відомостей в кримінальному провадженні. У той же час наголошується, що зазначене має інформаційне, орієнтуюче значення для окреслення шляхів подоланні проявів протидії кримінальному судочинству.

У висновках надається визначення інформаційного забезпечення подолання протидії кримінальному судочинству.

Ключові слова: кримінальне судочинство, провадження, подолання протидї, інформачія, інформачійне забезпечення.

Problem statement. The effectiveness of the investigation of criminal offenses in the context of counteraction is conditioned by the level of information support of this process. On the one hand, the information received in a timely manner is based on the cognitive activity of the investigator, on the other - the decision making by the investigator of optimal decisions. At the same time, the analysis of statistics of the Prosecutor General's Office of Ukraine [1] makes it possible to emphasize that in $60 \%$ of criminal proceedings the police did not collect sufficient information. It did not allow to make informed decisions, including the involvement of relevant persons for committing socially dangerous acts.

(C) Pletenets V., 2019

ORCID iD: https://orcid.org/0000-0002-3619-8624

k_ksmp@dduvs.in.ua 
Unpunished criminals continue to commit more grave and daring socially dangerous acts, taking measures to counteract criminal justice, including the destruction, alteration or concealment of information relevant to establishing the circumstances of a criminal offense.

Analysis of publications that started solving this problem. On certain aspects of information support of crime investigation, such criminal scientists as: T.V. Averyanova, R.C. Belkin, O.O. Belov, V.V. Biryukov, O.B. Dronova, V.A. Zhuravel, I.O. Jerusalimov, P.P. Ishchenko, E.D. Lukyanchikov, I.V. Piryg, V.V. Tyshchenko V.Yu. Shepitko, K.O. Chaplinsky and others.

Forensic scientists paid attention to the investigation of the problems of counteraction to the investigation: O.V. Alexandrenko, I.V. Gritsyuk V.M. Karagodin, I.A. Nikolaychuk, V.V. Trukhachov, E.V. Babayeva, S.Yu. Zhuravlev, L.V. Livshits, B. Ya. Kulikov, R.V. Mudretsky, A.N. Petrova, O.I. Romtsiv, R.M. Shekhavtsov, B.V. Shchur and others.

At the same time, no attention was paid to the information support of overcoming criminal justice by criminal scientists. This also leads to the difficulties faced by law enforcement agencies in the investigation and judicial review of the counteraction proceedings.

The situation is better seen in a systematic approach to research, in which information support issues would be considered through the prism of the needs of the employees of practical units in overcoming manifestations of counteraction to criminal proceedings by interested parties. This is conditional on objective expediency, since the existing studies alone cannot provide for the needs of practice in fulfilling the tasks of combating crime.

The article's objective is to outline the possibilities of information support in overcoming manifestations of counteraction to criminal justice.

Basic content. The organized nature of the criminal activity necessitates the introduction of effective measures, the use of information available to law enforcement. Only because of this, as V.E. Tkalich points out, is it possible to have an effective preventative effect on all criminogenic factors that determine crime. The role of information technology in combating crime is itself diverse. In operational and search activities, they can be successfully used to detect, document, disclose, prevent crimes and terminate criminal activity, including: in the early stages of their preparation, attempt and commission [2, p. 211-212].

Operational search activity also provides the process of investigating information that is otherwise difficult to obtain and sometimes impossible. This is of particular importance given the lack of information inherent in the initial phase of the investigation. This should be considered a necessary prerequisite for the implementation of tactical and operational measures, successful investigation with minimization of possible pressure from interested parties on the participants in criminal proceedings.

Information support, O.M. Bandurka emphasizes, is the core of the operational-search activity [3, p. 282].

Therefore, the systematic approach of law enforcement to information can reduce the time, effort and resources spent to produce a positive result.

The uncertainty with the organization of the investigation in general and the methods of overcoming the existing pressure from the interested parties in particular, is mainly the result of a lack of information from law enforcement. This affects the ability to make organizational and tactical decisions both in identifying areas of inquiry and in taking counter-measures.

Also noteworthy are the positions of scholars on the designation of information support for pre-trial investigation and judicial review of criminal proceedings.

Thus, according to A.M. Ishin`s of informational provision of pre-trial investigation, solves the following questions: the choice of subjects of information gathering, their competence; definition of terms, procedure and methods of obtaining, recording, processing and systematization of the received information; analysis of information in the framework of a certain procedure, using standard methods and involving appropriate specialists; organization of use of results of information analysis in practical activity of bodies of preliminary investigation [4, p. 22].

Thus, the possibility of obtaining information promptly necessitates the improvement of interaction between different law enforcement units. It is possible to achieve this, first of all, by consolidating efforts, comprehensively solving the problems of informational support of the activity of law enforcement agencies in overcoming manifestations of counteraction to criminal justice.

Information security is a special form of control over those threats that may come from crime $[5$, p. 146].

It is worth noting that crime is one of the main challenges for the state and its institu- 
tions. It is a systemic phenomenon that requires an integrated approach, coordinated with the efforts of the concerned state bodies. The same attitude is required for themselves against criminal proceedings. Measures to overcome them, for the most part, are taken from the moment they are diagnosed. However, the activities of law enforcement can also be carried out to the hypothetical possibility of pressure from stakeholders. The effectiveness of taking measures both to overcome and prevent the manifestation of counteraction to criminal justice depends directly on the timely receipt and use of the necessary information.

Actual direction of information support of the process of combating crime is the elimination of haphazardness in the collection of information, inconsistency between different entities in the analysis of information on the criminal situation and the development of response measures, in case of its complication, which as a result does not allow to make an effective management decision and reduces the level of their implementation [6, p. 107-108].

Systematicity, in our opinion, should be not only in the collection of information, but also its use in criminal proceedings. Yes, skillfully applied tactical techniques are the key to effective investigative (investigative) action, which in turn acts as a basis for the formation of evidence in criminal proceedings. Activity from the use of a particular tactical admission to the investigation should generally be based on the information available to law enforcement officers, the determination of what is to be obtained and the forecast of the realization of this goal, including taking into account the existing pressure from stakeholders.

At the same time, factors that may affect the effectiveness of information support need to be highlighted.

So, first, it is an opportunity for law enforcement officers to quickly access the necessary information. This should be considered as an objective factor independent of the will of the employees, since obtaining information, for most of them, has a complicated procedure that is carried out through agreement with the relevant executives or - a formal request. However, part of the databases is not automated, which necessitates the need for resources (human, temporary) to process the request. If, however, the need for access to information in criminal proceedings repeatedly arises, then the cost of obtaining it increases proportionally. The bureaucratic and outdated approach to data-driven activities, on the one hand, negates the promptness of data collection and, on the other, increases the number of informed officials and the possibility of early leakage of information and as a result of pressure from stakeholders.

Our position is also confirmed by studies conducted in Germany, according to which access to information bases is determined by the necessary factor for improving the activities of law enforcement agencies. At the same time, the main criteria for the organization of information support include: reliability, completeness, efficiency, availability of formalization of the description of forensic information, taking into account the display of potential evidential information, validity and, finally, accessibility for all subjects of investigation [7].

Secondly, there is an interconnected relationship between the moment of receipt and the use of the information. Yes, the less time it takes to get information to use it, the more impact it can have. The choice of the moment of application is subjective and should be conditioned, including by a factor of suddenness in the attainment of tactical goals by law enforcement, as well as taking into account that data, in the time of information technologies, are losing their relevance very quickly. This, on the one hand, determines the need for prompt, and on the other - timely use of information.

Thus, access to automated information bases for law enforcement officials should be simplified. This will ensure greater efficiency not only in the application, but also in minimizing the early leakage of information and counteracting criminal proceedings by interested parties.

The need for repeated use in the investigation of criminal offenses of the accumulated data sets necessitates the formation of forensic information systems, which act as a means of information support of investigation in general and overcoming manifestations of this activity, by interested parties in particular.

Information systems are understood to mean an organizationally ordered set of information sets about objects and information technologies, including modern computer hardware, software and communication networks, which provide processes for input, processing and delivery of information [8, p. 11].

Thus, the information security of the police is an organic unity of work to determine the content, volume, quality of information required for management, as well as measures for the rational organization of the collection, systematization, accumulation and processing of this information by applying a variety of methods, techniques and technical means [9, p. 161]. 
The above requires from law enforcement not just accumulation, but first and foremost systematization of information in the form of a simple, logically-built and intuitive, from the first application, structure. Because the need to understand the multifunctionality of the information system, for the most part, carries an unnecessary emotional burden, so as a result of its use in law enforcement may create a stereotype of unjustification and inappropriateness of time and effort to obtain the necessary data. This, in our opinion, is a significant component in the information support of the activities of law enforcement.

A special place in the information support of criminal proceedings is occupied by descriptions of objects contained in records. Their main purpose is to provide information about the availability of data about the object and its location at the time of the request, which will assist law enforcement agencies in the prevention, detection and investigation of criminal offenses.

Also, as the scientists point out, the following main tasks are being solved: identification of detainees and arrested persons; obtaining information about the past criminal activity of persons, subject to an on-going investigation or criminal proceedings, etc. [10, p. 91].

Of particular importance is the information support of judicial proceedings related to the analysis and legal evaluation of evidence gathered in criminal proceedings. The introduction of modern information technologies into the specified activity requires the creation of such a subject information environment that will provide the judge with the necessary data, minimize its costs for technical work, which as a result will contribute to the quality and promptness of the judge's decision-making [11, p. 83]. It should be noted that in the case of improper treatment of pre-trial investigators, these manifestations will inevitably affect the court in criminal proceedings.

In the course of the trial, the counteraction not only disappears, but can also take on new forms and ways of influence, characterized by the expansion of the range of subjects, the pursued goals [12, p. 97].

Thus, in our opinion, the presence of an information environment will help to minimize the pressure during the criminal proceedings, which will ensure that the court will not only make quick decisions, but first of all, grounded decisions.

Information on counteraction to criminal proceedings will necessitate the adoption of appropriate measures by law enforcement. Thus, in the presence of internal pressure, investigators mostly resort to organizational and tactical actions, adjusting plans, changing the sequence and timing of investigative (investigative) actions, taking measures to ensure the safety of participants.

In the case of external counteraction, for the most part, the management of the investigative unit is informed, the procedural supervisors, the proceedings may be transferred for investigation to the higher divisions. Persons who exert pressure must be held accountable.

The aforementioned list of measures is indicative only, and their division is conditional, since they can be taken on the facts of internal as well as external opposition to criminal proceedings. However, the aforementioned has an informative, indicative value for outlining the ways of overcoming manifestations of counteraction to criminal justice.

The main tasks of functioning of the information system of the organs of internal affairsorgans of internal affairs are:

- ensuring the ability to promptly receive information in a complete, systematic and easy-to-use form for disclosure by police officers and units;

- ensuring dynamic and effective information interaction of all sectoral police services of Ukraine, other law enforcement agencies and state institutions; security of information. The police also use other information support. For accessibility, it can be divided into open and closed security. Open is the provision of external public use, for example, regional address files (address bureaus), and closed - limited use, for example, operational reference files of information sources, intended only for a certain category of employees admitted to operational search activities. Some MIA services create their own specific information systems that support the functional activity of the structure. Such systems have the General Directorate of Fire Protection, the State Security Service, Medical Administration and some others;

- investigating, preventing and investigating criminals; collection, processing and generalization of operative, operative-search, operative-reference, analytical, statistical, and control-information for assessment of the situation and making reasonable optimal decisions at all levels of activity of police bodies [13].

At the same time, improving the activities of law enforcement agencies not only in the formation of information bases, but also the use of information contained in them, taking into 
account modern technical capabilities, available experience of their use in our and other countries, will increase the satisfaction of the needs of practice.

Conclusion. In the framework of this work, we have made only an attempt to outline the possibilities of informational support in overcoming the counteraction to criminal justice, which require more thorough scientific research, which cannot be realized within the article.

Despite the aim of the original study to suggest an original definition, we consider it possible to note the following. Yes, the formation of information in the form of simple, logically constructed with automated access to the data sets by its collection, analysis, research and systematization in accessible for further free, repeated use by law enforcement agencies of information both in the framework of investigation, judicial review of criminal proceedings in general, and those for which are counteraction and, in our understanding, information support for overcoming counteraction to criminal justice.

Opportunity to receive information promptly necessitates the improvement of interaction between different law enforcement units. The implementation of this should be carried out, first of all, through the consolidation of efforts and comprehensive solution to the tasks of informational support of the activities of law enforcement agencies in overcoming manifestations of counteraction to criminal justice.

Improvement of the activity of law enforcement agencies not only in the formation of information bases, but also the use of information contained in them, taking into account the current technical capabilities, available experience of their use in our and other countries, will increase the satisfaction of the needs of practice.

The directions of our further scientific research will be directed to the study of information technology capabilities in the activities of law enforcement agencies in overcoming manifestations of counteraction to criminal justice.

1. Сeferences

1. Єдиний звіт про кримінальні правопорушення України. URL

http://www.gp.gov.ua/ua/stat.html.
2. Ткаліч В. Є. Використання інформаційних технологій та засобів масової інформації при розкритті злочинів. Сторіччя розшуку: історія, сучасність та перспективи: Науково-практичн. конф. (м. Одеса, 24 жовтня 2009 р.). Одеса, 2009. С.211-212.

3. Бандурка О.М. Оперативно-розшукова діяльність: підручник. Харків: ХНУВС, 2002. $334 \mathrm{c}$.

4. Ишин А. М. Информационное обеспечение предварительного расследования преступлений: некоторые современные аспекты. Вестник Балтийского федерального университета им. И. Канта. Сер.: Гуманитарные и общественные науки. 2016. № 4. С. 21-28.

5. Желудков М. А. Особенности информационного обеспечения деятельности органов внутренних дел по противодействию эконо-мической преступности. Вестник Владимировского юридического института. 2007. № 3 (4). С. 146-149.

6. Годунов И. В. Некоторые аспекты информационно-аналити-ческой работы в деятельности правоохранительных органов в сфере противодействия преступности. Человек: преступление и наказание. 2012. № 4 (79). С. 107-108.

7. Kuhne, E. Polizeiliche Informationssysteme und ihre Nutzung in der Sachsischen Polizei. Berlin, 2004.

8. Бірюков В.В. Інформаційно-довідкове забезпечення розслідування злочинів: проблеми теорії і практики: автореф. дис. ... д-ра юрид. наук : 12.00.09 / Нац. акад. внутр. српав. Київ, 2011. 31 с.

9. Бандурка О.М. Управління в органах внутрішніх справ України: підруч. Харків : ХНУВС, 2009. $780 \mathrm{c}$.

10. Усманов Р. А. Информационные основы предварительного расследования : монография / под ред. А. А. Белякова. М. : Юрлитинформ, 2006. 367 с.

11. Правова інформатика: (система інформатизації законотворчої, правозастосовної, правоохоронної судочинної та правоосвітньої діяльності в Україні): монографія. Ужгород: IBА, 2003. $168 \mathrm{c}$.

12. Плетенець В.M. Криміналістичне забезпечення подолання протидії кримінальному судочинству: сучасний стан та шляхи розвитку. Eurasian Academic Research Journal. 2018. № 8 (26). 120 p.
13. Про
інформацію:
Закон
України від
02.10.1992p.
URL http://zakon4.rada.gov.ua/laws/show/1906-15.

Received to editorial office 09.12.2019

1. Yedynyy zvit pro kryminal'ni pravoporushennya Ukrayiny [Unified report on criminal offenses in Ukraine]. URL : http://www.gp.gov.ua/ua/stat.html. [in Ukr.]

2. Tkalich ,V. Ye. (2009) Vykorystannya informatsiynykh tekhnolohiy ta zasobiv masovoyi in- 
formatsiyi pry rozkrytti zlochyniv [The use of information technologies and media in crime detection]. Storichchya rozshuku: istoriya, suchasnist' ta perspektyvy: Naukovo-praktychn. konf. (m. Odesa, 24 zhovtnya 2009 r.). Odesa, S.211-212. [in Ukr.]

3. Bandurka, O. M. (2002) Operatyvno-rozshukova diyal'nist' [Operational search activity]: pidruchnyk. Kharkiv: KhNUVS, 334 s. [in Ukr.]

4. Ishyn, A. M. (2016) Informatsyonnoye obespecheniye predvarytel'noho rassledovaniya prestupleniy: nekotoryye sovremennyye aspekty [Information support of preliminary investigation of crimes: some modern aspects]. Vestnyk Baltyyskoho federal'noho unyversyteta ym. I. Kanta. Ser.: Gumanytarnyye i obshchestvennyye nauki. № 4. S. 21-28. [in Russ.]

5. Zheludkov, M. A. (2007) Osobennosti informatsyonnogo obespecheniya deyatel'nosti organov vnutrennikh del po protivodeystviyu ékonomicheskoy prestupnosti [Features of information support of activity of law-enforcement bodies in combating economic crime]. Vestnik Vladimirovskogo yuridicheskogo instituta. № 3 (4). S. 146-149. [in Russ.]

6. Godunov, I. V. (2012) Nekotoryye aspekty informatsyonno-analiticheskoy raboty v deyatel'nosti pravookhranytel'nykh organov v sfere protgvodeystvgya prestupnosti [Features of information support of activity of law-enforcement bodies in combating economic crime]. Chelovek: prestupleniye i nakazaniye. № 4 (79). S. 107-108. [in Russ.]

7. Kuhne, E. (2004) Polizeiliche Informationssysteme und ihre Nutzung in der Sachsischen Polizei [Police information systems and their use in the Saxon police]. Berlin. [in Ger.]

8. Biryukov, V.V. (2011) Informatsiyno-dovidkove zabezpechennya rozsliduvannya zlochyniv: problemy teoriyi i praktyky [Information support for crime investigation: problems of theory and practice]: avtoref. dys. ... d-ra yuryd. nauk : 12.00 .09 / Nats. akad. vnutr. srpav. Kyyiv, 31 s. [in Ukr.]

9. Bandurka, O. M. (2009) Upravlinnya v orhanakh vnutrishnikh sprav Ukrayiny [Management in the Internal Affairs Bodies of Ukraine]: pidruch. Kharkiv : KhNUVS, 780 s. [in Ukr.]

10. Usmanov, R. A. (2006) Ynformatsyonnye osnovy predvarytel'noho rassledovanyya [Information bases of preliminary investigation] : monohrafyya / pod red. A. A. Belyakova. M. : Yurlytynform,. 367 s. [in Ukr.]

11. Pravova informatyka: (systema informatyzatsiyi zakonotvorchoyi, pravozastosovnoyi, pravookhoronnoyi sudochynnoyi ta pravoosvitn'oyi diyal'nosti v Ukrayini) [Legal informatics: (system of informatization of law-making, law enforcement, law enforcement judicial and law-enforcement activity in Ukraine)]: monohrafiya. Uzhhorod: IVA, 2003. 168 s. [in Ukr.]

12. Pletenets' V.M. (2018) Kryminalistychne zabezpechennya podolannya protydiyi kryminal'nomu sudochynstvu: suchasnyy stan ta shlyakhy rozvytku [Forensic Support for Overcoming Counteraction to Criminal Justice: Current State and Ways of Development]. Eurasian Academic Research Journal. № 8 (26). 120 p. [in Ukr.]

13. Pro informatsiyu [On information]: Zakon Ukrayiny vid 02.10.1992r. URL : http://zakon4.rada.gov.ua/laws/show/1906-15. [in Ukr.]

\section{Summary}

The article emphasizes that the uncertainty with the organization of the investigation in general and the methods of overcoming the existing pressure on the part of the interested parties in particular, is the result of the lack of information from law enforcement. This affects the ability to make organizational and tactical decisions both in identifying areas of inquiry and in taking counter-measures. Emphasis is placed on the importance of using information technology in the activities of law enforcement.

Keywords: criminal justice, proceedings, countering, information, information support. 